\title{
TRANSATLANTIC RELATIONS AND GEOPOLITICAL FRAGILITY IN THE EASTERN MEDITERRANEAN REGION
}

\author{
Professor Ioannis M. NOMIKOS, Ph.D..$^{345}$ \\ Ms. Raagini SHARMA ${ }^{346}$
}

\begin{abstract}
The landmasses of the USA and EU which are on the opposing sides of the Atlantic Ocean have come into focus once again, socially and culturally linked ideals, such as democracy and human rights were always the backbone in the transatlantic relationship along with the joint commitments for free-market capitalism which were entrenched within the interests of the two major partners. The transatlantic relationship is reportedly plagued by difficulties. Since the establishment of NATO in 1949, transatlantic relationship has been at the centre of discussions for the United States and Europe. It keeps the two regions working together to combat the challenges in the world where there are conflicts. Common Institutions and Shared Identity are the core principles which unites the two regions. From relations with Russia and China to the policies on Iran and Syria's weapons control and climate change, transatlantic relations have arisen on world affairs today. On the other hand the geopolitical dynamics with the recent discoveries of significant natural gas deposits in the East Mediterranean region in the offshores of Cyprus, Egypt, Greece, Israel has become a hot spot for energy extraction. With the discovery of Eastern Mediterranean's natural gas fields like Tamar, Leviathan, Zohr and Aphrodite, and it has made transformative effect on the region. Energy is going to be crucial for future economic development in the Eastern Mediterranean region. The recent gas discoveries have been anticipated as offering an impetus for new levels of energy cooperation, as well as generating space for a larger power base and solidifying stability in the region.
\end{abstract}

Keywords: EU, USA, NATO, East-Mediterranean Sea, Russia, China, Energy, Security.

It is presumed that there will be a more hopeful and fruitful process for transatlantic ties under the new administration of President Joe Biden. The biggest challenge to the transatlantic relationship is creating a mutually beneficial agenda that is more than just expanding the trade links established between the two continents in the past and being more specific about what can be done in the future. Predictable collaboration between the United States and European Union holds key intersections in the fields of environment, human rights, intelligence, and

\footnotetext{
${ }^{345}$ Professor John M. Nomikos is Director of the Research Institute for the Research Institute for European and American Studies (RIEAS), Chairman of the European Intelligence Academy (EIA) based in Athens, Greece and founding editor of the Journal of European and American Intelligence Studies (JEAIS). Dr. Nomikos is head of the department of international relations, history, and politics in the Webster University Athens.

${ }^{346}$ Ms. Raagini Sharma is a Senior Analyst at the Research Institute for European and American Studies (RIEAS). She was former research coordinator at Global Counter Terrorism Council (GCTC) based in India.
} 
trade which has diminished over the years. Nevertheless, there are notable amounts of future opportunities in the areas such as economic development, foreign policy, security, and defence.

The way the world events are unfolding in the backdrop of the global pandemic, the United States and Europe are experiencing several common challenges; these include combatting the pandemic; infusing the economic growth and reinvigorating the trade ties constrained by the frequent lockdowns; strategies to counter the economic growth, military expansion and rising global dominance of the dragon country, China; responding to the geopolitical fragility in the East Mediterranean Region due to the energy resources found on the onset of $21^{\text {st }}$ Century and the claims of the countries in this region over the Exclusive Economic Zones; Gaza imbroglio that may turn into a major conflict between Israel and West Asian countries; apart from the common concerns over the climatic changes, immigrants issues, health care and inequality. The People's Republic of China has become the focus of international attention because of being the trigger for the global pandemic. China's growing political and economic clout worldwide and hegemonic inclinations that have the potential to drastically diminish the dominance of the USA and EU in global economic and political affairs is a cause of concern for both the US and EU.

The landmasses of the USA and EU on the opposing sides of the Atlantic Ocean have come into focus once again after Joe Biden has taken his seat at the office as the $46^{\text {th }}$ President of the United States, which may result in the shifts in the way the US deals with the regional and global affairs and may lead to different perspectives on the major issues cross-cutting the priorities - combatting COVID 19, reviving the economy, opposing views and responses towards climate change, re-orienting military and foreign policies and finding solutions to racial equity. Military and economic might will continue to be important factors for the US, but soft power will become more dominant. Similarly, for the EU, the priorities will be to combat COVID 19, vaccinating the population, minimizing the virus surges; redress the stressed economy; fighting the migrants' issues; energy security, and playing a much wider role in global political and economic affairs.

Add to this, the geopolitical dynamics with the recent discoveries of significant natural gas deposits in the East Mediterranean region in the foreshores of Cyprus, Egypt, Greece, and Israel. The Eastern Mediterranean region has become a hot spot for energy extraction and thus has become a distinct geographic area of great interest, concern and anxiety to regional countries and another fresh energy resource for energy-hungry countries globally. The region thus may become a flashpoint of grave concern in the future. Though there are several challenges, first, most of the resources are in deep waters, thus making it expensive to extract and second, the conflict between countries over the Exclusive Economic Zones (EEZ). Since the discovery of offshore natural gas reserves in the Eastern Mediterranean Region in the early 2000s, Turkey has challenged its 
neighbours with regard to the delimitation of their EEZ and destabilised the whole region through its illegal exploration and military interventions, in violation of international law. It is extremely significant for Greece and Cyprus to sign EEZ agreement as soon as possible in the near future. Inadequate infrastructure, limited local economies, and geopolitical uncertainties exacerbate these difficulties as well. The creation of the Eastern Mediterranean Gas Forum (EMGF) in the wake of growing conflicting issues responds to the need for a regionally organised initiative to fully realise the potential of the Eastern Mediterranean's offshore gas resources.

The first section of the paper discusses the history and the relationship between the transatlantic regions, how important it is to the transatlantic communities and about the latest developments in Transatlantic Trade and Investment Partnership. The second section explains in brief the geopolitical and economic shifts that may be caused due to the tensions in the Eastern Mediterranean region and the issues of Energy Security in this region including the formation and purpose of EMGF. The analysis draws the convergence between the two issues and the way ahead.

\section{TRANSATLANTIC RELATIONSHIP BETWEEN \\ THE USA \& THE EUROPEAN NATIONS}

Since World War I, the USA and European nations across the Atlantic Ocean had been cooperating in the areas of politics, security, economics and culture. Socially and culturally linked ideals, such as democracy and human rights were always the backbone in the transatlantic relationship along with the joint commitments for free-market capitalism which were entrenched within the interests of the two major partners. The two sides of the Atlantic used this partnership to bond with each other, which included contribution of time and effort to work together and support each other actively. Over the past seven decades, the United States has been the major force behind the transatlantic partnership, feeling that it is of utmost importance to the national security to garner maximum support from European countries as well as essential in terms of the country's economic well-being.

Transatlantic relations grew manifolds with the formation of the North Atlantic Treaty Organization (NATO) post World War II in April 1949 with firmly and formally sealing the alliance between the USA, Canada and ten European countries at that time based on the common motive to safeguard the freedom and security of all its members by political and military means. Collective defence was at the heart of this alliance fostering the spirit of solidarity and cohesion among its members.

The NATO was expanded to include states from Central and Eastern Europe in December 1991 and January 1994, respectively, through the North Atlantic Cooperation Council (NACC) and the Partnership for Peace (PfP) 
initiatives. In the beginning, NATO was founded to secure Europe, help protect the US soil and the Atlantic Treaty allies in the world. The post-World War II transatlantic partnership, which the United States dominated, was built on alliances with like-minded democratic countries and a joint commitment by the United States and Europe for a free economy and an inclusive international trading system. The United States has contributed to the EU's progress and development since the early 1950s, supporting the unification process of European integration. It was a means to enhance national cohesion, spur growth, and foster democratic institutions and free-market economics. Over the period of time, European countries joined NATO bringing 30 member countries into its ambit. ${ }^{347}$

When the United States became engulfed in the crisis of Afghanistan and Iraq, transatlantic ties and dialogue started waning. United States always believed that NATO and European integration would hold power to counter the Soviet army. The financial crash of 2008-11 and the Obama presidency signalled a reinvigoration of the ideology and laws of multilateral procedure in the United States. Obama's demands for European countries to hold power in front and handle the crisis of its neighbours and for more equitable responsibility in Afghanistan sparked debate. Europeans have often questioned the transatlantic alliance's potential to provide greater stability and peace. Obama's frequent portrayal of himself as uninterested in European matters had only contributed to the general feeling of scepticism and disillusionment.

The transatlantic relationship is reportedly plagued by difficulties. During Trump's presidency, he and his administration criticised NATO's strategic importance and the EU and its multilateral trading mechanism. He also called the EU as the "biggest foes" ${ }^{348}$ and Germany as "stupid". ${ }^{349}$ He portrayed that the EU trade policies were unfair to U.S. workers and businesses ${ }^{350}$. On the other hand, since its establishment in 1949, NATO has been at the centre of discussions for the United States and Europe. It keeps the two regions working together to combat the challenges in the world where there are conflicts.

The Atlantic Community was instrumental in creating the international multilateral system that grew out of the Second World War. The establishment of the United Nations and Bretton Woods System were the two organisations that gave the reflection for multilateral world order. The West since the inter-war period holds the responsibility for maintaining global peace, prosperity, and

\footnotetext{
${ }^{347} \mathrm{https} / / / \mathrm{www}$. nato.int/cps/en/natohq/topics_52044.htm 2 accessed on 01.05.2021.

348 Contiguglia, Cat., Trump: EU Is One of United States' Biggest Foes, "Politico", July 15, 2018. Online at: https://www.politico.eu/article/donald-trump-putin-russia-europe-one-of-united-states-biggest-foes/, accessed on 01.05.2021.

${ }^{349}$ Bloch Agneska and James Goldgeier, Reviving the Transatlantic Relationship, Brookings-Robert Bosch Foundation Transatlantic Initiative. November 2020, https://www.bosch-stiftung.de/en/story/revivingtransatlantic-relationship, accessed on 01.05.2021.

${ }^{350}$ Archick K., Akhtar, S. I., Belkin P. and Mix Derek. E. (2020), "Transatlantic Relations: U.S Interests and Key Issues", Congressional Research Service, https://fas.org/sgp/crs/row/R45745.pdf, accessed on 01.05.2021.
} 
stability around the word. The term Transatlantic Security Community has three characteristics: Interdependence, Common Institutions and Shared Identity. ${ }^{351}$ They believe themselves to be equal partners. For one thing, violence isn't really an option for both the U.S and European Union; their solidarity, their interdependence on political decisions, trade and economic relations, belief in democracy and human rights shows the correlation between the two lands across the Atlantic. From relations with Russia and China to the policies on Iran and Syria's weapons control and climate change, transatlantic relations have arisen on world affairs today.

The post-cold war period for transatlantic relations was important for the development both from economics and military point of view. Over the years, cumulatively the Purchasing Power Parity (PPP) and Foreign Direct Investments (FDI) of both the US and EU rose to extreme heights. The defence budget for NATO was much higher compared to Russia, China, or Brazil. NATO as an organisation evolved from territorial defence-based alliance into a security actor specializing in crisis management. ${ }^{352}$ Following the end of the Cold War, the focus of Western nations was on globalisation; as an advantage for development rather than a threat or challenge. ${ }^{353}$ Thus, globalisation resulted into a worldwide practise more specially for the United States, through the development of technology, social democracy, economic interdependence, and free market economy. For European Union countries, their agenda was to integrate and build strong interconnections between the Union countries. Therefore, the dissemination of globalisation spanned across oceanic borders, exhibiting the substantial intercultural relations and activities of the transatlantic community.

The escalation in China's position on the global economy ladder was much less drastic than the United States' invasion on Iraq in 2003 which had repercussion on the transatlantic relationship. Previous incidents of transatlantic conflict that dealt with such issues, such as the Suez Crisis and the Iraq war, are now being served as case studies for researchers in this field of study. During the tenure of Trump as the President, the allies of United States and amongst those, the Western European allies suffered severely. He criticized the European Union and its strong integration. President Joe Biden has made economic growth a top priority in the wake of the global pandemic "COVID-19", which has struck the world hard. He also wants to put a stop to the continuing trade war or the so-called artificial trade war between the US and Europe. ${ }^{354}$

\footnotetext{
${ }^{351}$ Risse, Thomas (2003), Beyond Iraq: Challenges to the Transatlantic Security Community, Washington, D.C, American Institute for Contemporary German Studies at the Johns Hopkins University.

352 Goldgeier, James M (1999), Not Whether but When. The U.S Decision to Enlarge NATO, Washington, Brookings Institution Press.

353 The New Transatlantic Agenda (1995), https://eeas.europa.eu/archives/docs/us/docs/new transatlantic_agenda_en.pdf, accessed on 01.05.2021.

${ }^{354}$ Bloch Agneska and Goldgeier James (2020), Reviving the Transatlantic Relationship, Brookings-Robert Bosch Foundation Transatlantic Initiative, https://www.bosh-stiftung.de/en/story/reviving-transatlantic-relationship, accessed on 01.05.2021.
} 
According to Samuel Huntington's, The Third Wave - Democratization in the late twentieth Century, ${ }^{355}$ western ideas of liberal democracy and supply-side economics began to reach Europe and NATO through enlargements and since then has gradually expanded to include other areas of the world through financial donor contributions from countries as well as International Financial Institutions (IFIs). In the international arena, Europeans and Americans remained largely dependent on one another, paradoxically attesting to the continuing importance of an Atlantic culture.

Since the beginning of $21^{\text {st }}$ century, there has been a shift of power in the global order. John J. Mearsheimer in his book, 'The Tragedy of Great Power Politics' mentions that the world has shifted from bipolar world to multipolar world after the cold war. ${ }^{356}$ The transatlantic partnership has been influenced not only by systemic developments on a global scale, but also by actor-level shifts within the United States and Europe. Also, the 2008 financial crisis shifted the course of transatlantic relationship. Domestic politics, economy, and social structure have built the inter-connectedness between the European nations. With the strong integration of the European Union, the nations have become more dependent on each other leading to stronger cohesion and simultaneously diluting the US-EU ties. The annual EU-US summits used to showcase the common agendas and shared vision in their relationships. For some years, their packed agendas, which included policies and programmes ranging from banana tariffs to cyber-security and Kosovo independence, reflect the multifaceted nature of today's transatlantic ties.

Officials in Europe express concern about dwindling and delayed consultations on foreign policy and security matters that could lead to a gap in relations between the US and Europe. These concerns include the withdrawal of US troops from the international coalition battling the Islamic State terrorist group in Syria in 2019 and the death of an Iranian military officer by a US drone attack in early 2020, which exacerbated the situation in the Persian Gulf.

The United Kingdom's withdrawal from the EU (popularly known as "Brexit"), the negative economic consequences of the COVID-19 pandemic, a persistent terrorist challenge, Russia's rise, and a dynamic China are only a few of the reasons why the relationship between the US and the EU in 2021 has changed, and many questions have been posed about the future and their position on the global stage. The waning and downturn in cooperation between the U.S. and U.K. may signify a significant shift in how transatlantic ties have been managed since World War II, which has been changed with the Brexit deal. The historical and cultural affinity between the two has suffered because the Britain has always served as the U.S. gateway of entry into the EU in the past. The United States

\footnotetext{
${ }^{355}$ Huntinggton, Samuel P. (1991), "The Third Wave. Democratization in the Late Twentieth Century", Norman, University of Oklahoma Press.

${ }^{356}$ Mearsheimer John J. (2001), The Tragedy of Great Power Politics, New York, Norton.
} 
must manage the relations with both U.K and Franco-German axis from European Union side. There's a firm conviction that Britain will continue to be a close partner regardless of whether it is a member of EU, it will still contribute to the European security as well as be a key member of NATO.

Both the United States and the EU member states will have to move together in diplomatic collaboration, with respect to separate EU foreign policy initiatives, such as Common Foreign and Security Policy (CFSP) and Common Security and Defence Policy (CSDP). Intelligence cooperation is the most important weapon in the battle to contain the new threats (biological warfare, CBRNE, radical extremism and organized crime, money-laundering) in the $21^{\text {st }}$ centuries. As Prof John M Nomikos, RIEAS director has pointed out that the European Commission needs to establish a European Union Intelligence Agency (EUIA) in order to create a "European Intelligence Culture" and coordinate actions on intelligence issues among the $27 \mathrm{EU}$ member-states.

In the world arena, the United Kingdom has consistently stood shoulder to - shoulder with America and its allies. Following Brexit, the US has accelerated its bilateral relations with Germany, the EU's dominant economic power. As the EU's second and third-largest economies, France and Italy have significant roles to play in transatlantic relations.

Transatlantic Trade and Investment Partnership (TTIP) is an agreement between the U.S and EU, a barrier free trade agreement. It was established in the year 2013. The agreement aimed at establishing the most extensive free trade zone in the world, spanning over the North Atlantic region. Over the period of time, it has created trade-related jobs, has provided the consumers to buy products at a lower price, expanded the economic integration and activity and has led the two regions to comply with the areas of food safety, energy security, environmental protection, and banking regulations. The primary goal of TTIP is to reduce tariff barriers between the United States and the European Union, which are used to regulate cross-border trade, to zero. The trading system has delivered great benefits over the past 75 years, billions of people have been lifted out of poverty, sickness, and despair, largely by export-oriented growth strategies. ${ }^{357}$

Trade relations, such as the availability of natural resources and other economic progress and sustainable growth, will benefit both regions. Noting the improvements currently irrespective of the few issues with Trump's trade policies earlier, there is a bright future for both the regions irrespective of the problems that have existed between the United States and Europe for years. International NGOs and businesses may also help to foster shared understanding among countries and communities, influencing mutual perspectives.

Both sides of the Atlantic are keen to restore the US-EU relationship. Among other agendas, energy conservation, security and cooperation could play

\footnotetext{
357 https://www.wilsoncenter.org/article/enhancing-transatlantic-trade-and-investment-relationship, accessed on 01.05.2021.
} 
a key role in reviving the relationship under Joe Biden's administration. There is a possibility that United States will be returning to multilateral global climate change agreements under the terms established in the Paris Agreement (2015), taking a critical step towards restoring faith with its transatlantic allies. Before leading on climate issues in a global arena, the United States must re-enter the Paris Agreement with modesty and prioritise limiting greenhouse gases and carbon emissions at home. The previous president of the United States overlooked the importance of the US-EU Energy Council, now its President Joe Biden's responsibility to make the council function and he should hold a larger role in global climate and energy work. It is critical that climate policy be incorporated into all fields of EU and US collaboration as it affects everything on the two of these three levels of politics, economics, and social concerns. However, welldesigned trade strategies will help move the energy transition forward towards the way the international community has set out with long-term sustainable development goals, including those agreed to in Paris. A ramped-up US engagement in global forums, such as the Clean Energy Ministerial and Mission Innovation will reinforce the efforts of the US-EU Energy Council. ${ }^{358}$ More effort should be put into the renewable energy programmes.

The EU's proposed Carbon Border Adjustment Mechanism (CBAM), a key component of the European Green Deal, will have significant implication on the US-EU relationship as the EU moves to impose a tax on imported goods based on their attributed carbon emissions. ${ }^{359}$ Energy is essential since the two different governing bodies, the US and the European Union, have different laws. Steps must be taken to ensure that the execution of policies fully complies with World Trade Organisation. While new, environmentally friendly developments are essential for stability, they are inevitably related to an increase in dependency on oil, hence making energy security a priority for both regions. US-EU must comply with robust and effective multilateral/ multinational collaboration with the expansion of transatlantic cooperation on the development of technologies is needed to ensure long-term security, availability and affordability of energy sources for the future generation. The United States and the European Union should maintain their role in the Three Seas Initiative and their place in the East Mediterranean Gas Pipeline Organization, also known as East Med. In relation to the sanctions on Iran, as well as on Venezuela, there should be cooperation; the penalties/sanctions should be implemented simultaneously with the consultation.

Over the years post-cold war after the breakup of Soviet Union and ushering of the digital world with paradigm shifts in the way the businesses happen and economies prosper, there have been dilutions in the spirit of the alliance and

\footnotetext{
358 Morningstar, R. (2021), "Prospects for Transatlantic Climate and Energy Cooperation”, Wilson Centre, https://www.wilsoncenter.org/article/prospects-transatlantic-climate-and-energy-cooperation, accessed on 01.05.2021.

359 Ibidem 9.
} 
diminishing of its trade, military and cultural ties and there have been voices within the US Congress who have protested the size of US military contributions to Europe into the NATO organisation and the much lesser involvement of European Nations towards the common causes. However, with changeover of the government in US, the Biden-Harris setup may lift the declining spirits of the alliance between US and EU and find common grounds and shared vision to carve a path of prosperity and stability.

\section{GEOPOLITICAL FRAGILITY EMANATING FROM NEWLY FOUND ENERGY RESOURCES IN EASTERN MEDITERRANEAN REGION}

The traditional sources of friction including protection of national sovereign, disputes over the territorial waters and strife between the different faiths in the East Mediterranean region among Greece, Cyprus, Israel, Egypt, Turkey and other nations are coupled now with the another set of interlocking geopolitical tensions and energy disputes in this region. Not only has the number of countries involved in the crisis grown, but also its scope has widened to embrace the new issue about recent energy discoveries in the Eastern Mediterranean region, that in, in turn, have qualitatively changed the nature of the crisis. Hinging upon the newfound energy resources are the expectations of nations of this region, and energy hungry USA and EU apart from other developing countries.

According to International Energy Agency's definition, energy security is the uninterrupted availability of energy sources at affordable prices ${ }^{360}$ Energy security may seem like an abstract concern, but certainly it is important, yet vague, and a little hard to pin down (Yergin, 2011, pp.267). Energy security encompasses not just the vast spectrum of supply of energy, availability, acceptability, and affordability, but also the relationships between nations, how they interact with one another, and how energy influences their wider national security issues. Affordable and sustainable access to energy resources has been one of the key challenges for all the countries around the world. In today's time for the countries, energy security has become vital in terms of the control of transportation routes and to protect critical infrastructure and key energy assets, this is more so important for those countries which depend on import of energy resources (Ebel and Menon, 2000). Energy and politics are part and parcel of one another and must not be split. It is an inextricable component of policies; it is often intertwined with developments, which is why states make it a part of their foreign and national security strategies (Yergin, 2006).

The Mediterranean Sea is located at the crossroads of Europe, Asia, and Africa; it encompasses major international sea routes and straits such as the Straits of Gibraltar, the Bosporus, the Dardanelles, and the Suez Canal; and it has oil and

\footnotetext{
${ }^{360}$ International Energy Agency Homepage, http://www.iea.org/topics/energysecurity/, accessed on 01.05.2021.
} 
natural gas reserves. ${ }^{361}$ The discovery of energy resources in the Eastern Mediterranean region has led to important geopolitical dynamics on sea and closest lands. It has also led towards instability in the region which thus has disrupted the balance of power in the region. The stability and changes in the balance of power in this region is dependent on factors such as optimally tapping oil resources, distributing to energy-hungry EU and other countries for economic growth, and maintaining it by alliances and diplomacy, for which infrastructure construction in the form of pipelines and infrastructure are critical. It is also believed, it triggered "bonanza" 362 among the countries to grab the opportunity of signing deals with the East Med countries for their profit.

The discovery thus has led to tensions between Israel, Turkey, Greece, Cyprus, and Egypt. ${ }^{363}$ The deposits in the Eastern Mediterranean could provide energy to the region's nations as well as external consumers such as energystarved Europe. It is estimated that the Eastern Mediterranean region, extending from Cyprus to Lebanon and from Israel to Egypt, hosts probably more than 340 trillion cubic feet (tcf) of natural gas (Lo 2017; Lavinder 2018). The exploration of new oil supplies provides an opportunity for energy-producing countries to reduce regional reliance on electricity while increasing economic growth. Greece and Cyprus are EU member states, and any potential EU-Eastern Mediterranean trade in energy supplies will expand their influence and jurisdiction through EU decision-making bodies' negotiations.

The Natural gas field across the countries in the Eastern Mediterranean has become a subject on which the countries' domestic and foreign policies codetermine. Regional gas governance systems with their traditional trade and pricing patterns have, therefore, begun to slowly crack, giving way to more globalized forms of gas trade. ${ }^{364}$

A plethora of potential export markets, as well as new cooperation possibilities, have arisen, allowing for greater coordination on the growth of the international gas industry. This figure increases the geostrategic importance of the Eastern Mediterranean and increases rivalry among states for hydrocarbon reserves. Supply disruption, for example, has often been used as an 'energy tool' by the generating state or transit states that dominate pipelines or transportation routes in order to compel the consuming state or coalition of consumer states to

\footnotetext{
${ }^{361}$ Sharma, R., (2021), "Energy Security in the Eastern Mediterranean Region: Challenges in $21^{\text {st }}$ Century", RIEAS, Available at: https://rieas.gr/researchareas/editorial/4609-energy-security-in-eastern-mediterraneanregion-challenges-in-the-21st-century, accessed on 01.05.2021.

362 Energy Post, (2019), East Mediterranean Gas Finds: EU energy Bonanza or geopolitical headache?, https://energypost.eu/east-mediterranean-gas-finds-eu-energy-bonanza-or-geopolitical-headache/, accessed on 01.05.2021.

${ }^{363}$ Mamedov, R. (2020), The Energy Sector, Competition and Security in the Eastern Mediterranean, Russian International Affairs Council, https://russiancouncil.ru/en/analytics-and-comments/analytics/the-energy-sectorcompetition-and-security-in-the-eastern-mediterranean/, accessed on 01.05.2021.

${ }^{364}$ Hulbert, M. \& Goldthatu, A. (2013), Natural Gas going Global? Potential and Pitfalls, "Handbook of Global Energy Policy", London, pp. 98-112.
} 
modify their behaviour in the manner desired by the adversary. Few scholars argue that high levels of securitization within nations are needed for peaceful political ties between nation-states, and most accept that lower levels of securitization are more prevalent in the East Mediterranean region. As there are numerous questions to be answered about energy protection in the Eastern Mediterranean region, the challenge is complex.

The interest shown by the US Company Noble Energy and the French company Total E\&P in the area became apparent since 2010. The offshores of Israel and Cyprus and their exclusive economic zones, or maritime zones, the corporations discovered a total of 3.4 tcf of recoverable gas and 1.7 billion barrels of recoverable oil reserves. Given the latest estimates of Zohr's capacity after the discovery of the giant gas field in the Egyptian offshore in 2015 (Nile Delta Basin) and the assumed 2-4 tcf feet of untapped natural gas and 1.5 billion of oil in the Aegean Sea specifically in Greek waters south of Crete, the total natural gas reserves in the Eastern Mediterranean could overcome 10 tcf (Indeo, 2016). For the U.S, the region has been the central focal point since the cold war era. The current rivalry between Greece and Turkey has alarmed the U.S and E.U regarding the recent developments and the conflicts happening in the region.

The discovery of natural gas fields such as Tamar, Leviathan, Zohr, and Aphrodite in the Eastern Mediterranean was a promising indication, and it had a profound impact in the region. It demonstrated a symbol of stability and unity in the area, but it has been unable to hold tensions between states. When discussing stability, especially the regionalization of the Eastern Mediterranean, it is important to remember a few constructs that have become political discourses in international relations studies, these narratives are as follows: exclusive economic territories, LNG ports, deep-sea water tunnels, and the UNCLOS. In other words, energy has the power to alter not just the geographic scope of an area, but also the practises and policies that govern it.

From a historical point of view, the ability to move energy across borders has been a source of savings and security and a basis for foreign commercial and diplomatic relations. ${ }^{365}$ Because of the region's turbulent terrain, building a pipeline is a difficult challenge. A series of discussions have taken place in Eastern Mediterranean countries over the construction of an 'EastMed' pipeline. The plans to build a pipeline to Europe have not been implemented yet; however, on 2 January 2020, Greece, Cyprus, and Israel signed a treaty to construct the 1,900kilometre East Med gas pipeline. ${ }^{366}$

\footnotetext{
${ }^{365}$ Verrastro, F. and Ladislaw, S. (2007), Providing energy security in an interdependent world, "The Washington Quarterly", Vol. 30, pp.95-104.

${ }^{366}$ Mamedov, R. (2020), The Energy Sector Competition and Security in the Eastern Mediterranean, "Modern Diplomacy", https://moderndiplomacy.eu/2020/12/20/the-energy-sector-competition-and-security-in-the-easternmediterranean/, accessed on 01.05.2021.
} 
The Eastern Mediterranean Gas Forum (EMGF) was established in 2019, headquartered in Cairo, Egypt, in collaboration with French and Italian energy companies, to coordinate gas trade, set prices, align energy policies, merge infrastructures and thereby secure energy supply. ${ }^{367}$ The EMGF will serve as a platform to foster cooperation and initiate a structured and systematic policy dialogue on natural gas, potentially leading to the development of a sustainable regional gas market. ${ }^{368}$ The forum includes Cyprus, Egypt, Greece, Israel, Italy, Jordan, and Palestine as member countries, but Turkey is not part of this forum. The exploration of gas deposits in the Eastern Mediterranean brought another dimension of dispute apart from decades-old conflicts amongst the countries regarding the exclusive economic zones (EEZs) and bilateral conflicts. The establishment of the EMGF responds to the need for a regionally coordinated effort to unlock the full potential of Eastern Mediterranean offshore gas wealth. ${ }^{369}$ The Eastern Mediterranean has been an effective pathway for EU oil and natural gas imports, with around 35\% of EU natural gas and 50\% of EU oil consumption trafficked within the region (Szoke, 2016). EMFG is trying to create energy routes to Europe with the initiation of pipelines or liquified natural gas terminals.

The East Med pipeline, under the forum which is sponsored by the EU, was signed by Greece, Cyprus, and Israel, with the aim of connecting the EU to the grid. The East-Med pipeline, which will connect Israel's fields to the Greek island of Crete, will need to face the illegal Turkish-Libya economic zone. Turkey is contentious and against this project, as earlier Turkey was the key transporting country for Russia's energy resources to European countries. This move explains that the East-Med Pipeline questions and rewrites the region's coastal and maritime borders. However, as a result of COVID-19, growth has halted and countries' economies have suffered. The region's energy consumption has been falling, and this has spread regionally and internationally as quickly as the virus. Nations such as the United States and Russia, as well as supranational Europe, have taken different approaches for obtaining resources from newly discovered gas fields, resulting in competition.

\section{CONCLUDING REMARKS}

The transatlantic relations between US and European nations historically share the common vision of peace and stability amongst themselves as also in the world as a whole. These goals and shared vision can only be achieved through

\footnotetext{
367 Wolfrum, S. (2020), Pipelines to Swords: How COVID-19 Shifted Focus from Energy Cooperation to Securitization in the Eastern Mediterranean, Observer Research Foundation, https://www.orfonline.org/expertspeak/pipelines-swords-how-covid19-shifted-focus-energy-cooperation-securitisation-eastern-mediterranean/, accessed on 01.05.2021.

${ }^{368}$ Press Release, (2019), Cairo Declaration establishing the East Mediterranean Gas Forum, Cairo, Available at: www.pio.gov. cy/en/press-releases-article.html?id=5590\#flat, accessed on 01.05.2021.

${ }^{369}$ Sukkarieh, M. (2021), The East Mediterranean Gas Form: Regional Cooperation Amid Conflicting Interests, Natural Resource Governance Institute, https://resourcegovernance.org/analysis-tools/publications/eastmediterranean-gas-forum-regional-cooperation-amid-conflicting, accessed on 01.05.2021
} 
strong economic and military ties. However, the mutual trust factor has been on decline over the years. Most damage to the ties has been during the Trump era. The US and EU must create improved collaboration opportunities for evolving the relationship. The challenges of the $21^{\text {st }}$ century are so diverse and unparalleled that no one country, neither the US or EU alone can adequately address these. On part of US, Biden-Harris administration has re-kindled the hopes for stronger ties by taking positive steps to rebuild this trust by highlighting the importance of the transatlantic relationship at the Munich Security Conference and selecting committed transatlantic experts for key foreign-policy posts. Likewise, European leaders are thinking through concrete ways to improve transatlantic ties. NATO must review the need for new strategic concepts, which would redefine the alliance's priorities in the pandemic-stricken world and the current security landscape. Ending the COVID-19 pandemic, reinvigorating transatlantic security, and reconciling US and European policies on technology should be the new touchstones. And to deal with these new touchstones, will require investments of time, resources, and political capital and will on part of both.

Russia tends to use an advanced toolkit that combines cyber, misinformation, malign banking, economic exploitation, and extremist help to destabilise the relationship between the transatlantic countries. China on the other hand is increasing its economic footprints in almost every continent. To combat the global dominance of China and rise of Russia, NATO and the European Union need to develop better strategies. Transatlantic ties are expected to develop into a network of various partnerships and agreements, creating an incentive for increased collaborations between Europe and the United States. Transatlantic partners must join hands to enact and firmly implement common laws to govern financial flows, ownership transparency, and information exchange, rather than just lip service to these issues.

Energy is going to be crucial for future economic development in the Eastern Mediterranean region. Several countries hope to create a unified energy market and expand energy networks, but due to COVID-19, the cooperation between the countries to build energy projects has been put on hold. There has been a notable shift in global oil markets, which has caused many policy makers and private investors to rethink the feasibility of cost-intensive energy projects due to which Eastern Mediterranean countries' approaches are now focused on security partnerships to combat competitions and threats. The recent gas discoveries have been anticipated as offering an impetus for new levels of energy cooperation, as well as generating space for a larger power base and solidifying stability in the region.

Europe is one of the largest consumers of gas, and East Med fields are located within almost thousand kilometers of the European shores. And hence, Europe's interests in this energy rich region are genuine. For USA, the energy is the single most important factor to have interest in East Mediterranean region. It 
has supported the formation of EMGF and has strengthened bilateral and multilateral relations with the nations in this region. US and EU, both have interests in this region primarily to tap the energy as also to counter any other countries' potential dominance in the region. Hence, US and EU are likely to work together in this region to utilize its energy resources as also put up a geo-economic counter weight to Russia's or China's designs.

\section{BIBLIOGRAPHY}

- Ayoo. C. (2018), “Towards Energy Security for the $21^{\text {st }}$ century”, Intechopen, https://www.intechopen.com/books/energy-policy/towards-energy-securityfor-the-twenty-first-century.

- Barkey, H. J. (2020), “What's Next in the Eastern Mediterranean?”, Council On Foreign Relations, Available at: https://www.cfr.org/article/whats-nexteastern-mediterranean.

- Bindi, F. (2019), "Europe and America: The End of the Transatlantic Relationship?" Brookings Institution Press, JSTOR, Available at: www.jstor.or/stable/10.7864/j.ctr75d89f.

- Charles, E., John R., Harry T., David K. (2016), "Hydrocarbon developments in the Eastern Mediterranean: the case for pragmatism", Eurasian Energy Futures Initiative, Atlantic Council, p. 17, available at: www.atlantic council.org/images/publications/Hydrocarbon_Developments_in_the_Easter n_Mediterranean_web_0801.pdf.

- Cropsey, S., Brown, E. (2014), “Energy: The West's Strategic Opportunity in the Eastern Mediterranean", Hudson Institute, Available at: https://www.hudson.org/content/researchattachments/attachment/1443/2014 _12_02_hudson_report_eastern_med_final_single_pages.pdf.

- Darbouche, H., El-katiri, L., Fattouh, B. (2012), "East Mediterranean gas: what kind of a game-changer?", Oxford Institute for Energy Studies (OIES), p. 4, available at: www.oxfordenergy.org/wpcms/wp-content/uploads/ 2012/12/NG-71.pdf.

- Hanhimaki J.N., Schoenborn B., Zanchetta B. (2012), "Transatlantic Relations since 1945. An Introduction”, London and New York, Routledge.

- Hass R.N. (2016), "Political Losses From Brexit Will Be Deep And Enduring”, Financial Times, Available at: https://www.ft.com/content/ 63769fb6-3a03-11e6-a780-b48ed7b6126f.

- Karnitschnig M., 2020. "What Biden Means for Europe: On Key Issues From Climate Change to China, How the Next US President Will Revamp Transatlantic Ties." Politico. November 8, 2020. Online at: https://www.politico.eu/article/what-joe-biden-means-for-europe/. 
- Lindley-French J., (2002) "Terms of Engagement: The Paradox of American Power and the Transatlantic Dilemma post-11 September, Paris, European Union Institute for Security Studies.I

- Le Corree P., (2016), “After Brexit, U.S. will need a ne BFF”, The Brookings Institution, Available at: https://www.brookings.edu/blog/order-fromchaos/2016/06/28/after-brexit-u-s-will-need-a-new-bff/.

- Van Oudenaren J. (2005) "Transatlantic Bipolarity and the End of Multilateralism." Political Science Quarterly, vol. 120, no. 1, pp. 1-32. JSTOR, Available at: www.jstor.org/stable/20202471.

- Yost D. S. (1998), "NATO Transformed. The Alliance's New Roles in International Security”, Washington, United States Institute of Peace Press. 